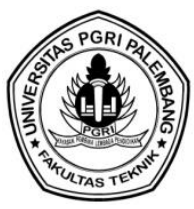

\title{
ANALISIS PEMBUATAN JOB MIX FORMULA ASPHALT CONCRETE BINDER COURSE (AC BC) DI PEMBANGUNAN JALAN TOL PALEMBANG - SIMPANG INDRALAYA (PALINDRA)
}

\author{
Agus Setiobudi \\ Program Studi Teknik Sipil Fakultas Teknik Universitas PGRI Palembang \\ Email : setiobudi808@gmail.com
}

\begin{abstract}
ABSTRAK
Kadar aspal optimum pada lapis Asphalt Concrete Binder Course (AC BC) dimana dalam pembuatan dilakukan di Laboratorium Aspal untuk membuat Job Mix Formula (JMF) di Proyek Tol Palindra. Dimulai dari pemeriksaan propertis bahan bitumen 60/70 dan agregatnya. Percobaan dilanjutkan dengan membuat sample berbagai variasi campuran kadar Asphalt Concrete Binder Course (AC BC) mulai dari 4\%, 4,5\%, 5,0\%, 5.5\%, 6\% dan 6,5\% dari hasil penelitian tersebut diperoleh kadar aspal optimum sebesar $5.3 \%$. Selain itu, pemakaian kadar aspal optimum 5.3\%, juga harus memperhatikan sifat agregat terdiri dari Abu batu, agregat ukuran 10-10 mm (Mediun Aggregat) dan 10-20 mm (Coarse Aggregat) yang semua berasal dari Ciwandan Merak Banten yang disediakan oleh PT. Diaz, dimana agregat diatas memiliki penyerapan rata-rata sebesar 1,5\% yang berarti daya penyerapan terhadap aspal terlewat pada batas maksimal yang diijinkan, yaitu sebesar 1.2\%. Kadar aspal optimum pada lapis Asphalt Concrete Binder Course (AC BC) dalam pembuatan proses pembuatan Job Mix Formula (JMF) di Proyek Tol Palindra diperoleh sebesar 5.3\% dengan pengujian karakteristik Marshall test pada Kadar Aspal Optimum 5,3\% didapat nilai density diperoleh sebesar 2,285 gr/cc, nilai VMA (Void in Mineral Aggregat) sebesar 15,18\%, nilai VFB (Void Filled Bitumen) sebesar 69,86\%, nilai VIM (Void In Mix) sebesar 4,57\%, nilai Stabilitas Marshall sebesar $1314,25 \mathrm{~kg}$, nilai Flow (kelelehan) sebesar 3,45 mm dan nilai Marshall Quotient diperoleh sebesar 254,04 $\mathrm{kg} / \mathrm{mm}$
\end{abstract}

Kata Kunci : Job Mix Formula, Asphalt Concrete Binder Course (ACBC), Marshall Test.

\section{LATAR BELAKANG}

Pada saat ini di Provinsi Sumatera Selatan telah dilaksanakan Pembangunan Jalan Tol pertamanya dimana Pelaksanaan Pembangunan Jalan Tol Palembang-Simpang Indralaya (PALINDRA), dimana kegiatan tersebut dilaksanakan oleh PT. Hutama Karya (Persero) sebagai Pemilik Proyek yang dilapangan di bentuknya PT. HKJT (Hutama Karya Jalan Tol), PT. Cipta Strada Konsultan sebagai Konsultan pengawasannya dan PT. Hutama Karya Infrastruktur (HKI) sebagai Kontraktor Pelaksananya. Waktu pelaksanaan dari pengawasan Pembangunan Jalan Tol Palembang-Simpang Indralaya (PALINDRA) ini selama 720 (tujuh ratus dua puluh) hari atau 2 (dua) tahun.

Pembangunan jalan bebas hambatan Tol Palindra berdasarkan basic design sepanjang $24,481 \mathrm{~km}$ terdiri dari $21,930 \mathrm{~km}$ jalan utama dan 2,551 km jalan akses $1,532 \mathrm{~km}$ jalan akses Pemulutan; 1,019 km jalan akses KTM Simpang Rambutan). Jalan utama sepanjang 21,930 KM terdiri dari 3 seksi, yaitu:

1. Seksi-1: Palembang-Pemulutan (Sta. 0+000 s/d Sta. 7+750) sepanjang 7,750 km.

2. Seksi-2: Pemulutan-KTM (Sta. 7+750 s/d Sta. 12+650) sepanjang 4,900 km.

3. Seksi-3: KTM-Simpang Indralaya (Sta. $12+650 \mathrm{~s} / \mathrm{d} 21+930$ ) sepanjang $9,280 \mathrm{~km}$. 
Pembangunan Jalan Tol Palindra memakai sistem perkerasan lentur (flexible pavement) pada jalan utamanya terdiri dari lapis 3 (tiga) lapis, diantaranya:

1. Lapis Pondasi aspal AC BASE COURSE (Asphalt Concrete Base Course) dengan ketebalan $11 \mathrm{~cm}$.

2. Lapis kedua aspal $A C B C$ (Asphalt Concrete Binder Course) dengan ketebalan $6 \mathrm{~cm}$.

3. Lapis ketiga aspal $A C W C$ (Asphalt Concrete Wearing Course) dengan ketebalan 5 $\mathrm{cm}$.

Material aspal memiliki sifat kohesif, adesif, dan termoplastis. Kohesif berarti sifat mengikat sesama komponen aspal, yang dapat dievaluasi melalui pemeriksaan daktilitas. Adesif adalah sifat mengikat material pada penelitian ini pada agregat di campuran Asphalt Concrete Binder Course $(A C B C)$. Sifat adesif dapat dievaluasi melalui pemeriksaan Stabilitas Marshall Test (Thanaya, 2008).

Sifat termoplastis adalah sifat aspal yang dipengaruhi oleh oleh perubahan temperatur (temperatur suceptibility). Aspal akan mencair bila dipanaskan, dan akan mengeras kembali bila didinginkan. Kualitas dan kuantitas aspal dalam campuran sangat berpengaruh terhadap kinerja campuran lapis perkerasan dalam menerima beban lalu lintas. Kadar aspal yang rendah dalam suatu campuran akan mengakibatkan lapis perkerasan mengalami retak-retak. Demikian juga kadar aspal yang berlebihan membuat lapis perkerasan mengalami bleeding. Oleh sebab itu, kadar aspal yang diperlukan dalam suatu campuran lapis perkerasan adalah kadar aspal optimum, yaitu suatu kadar aspal yang memberikan stabilitas tertinggi pada lapis perkerasan, dimana persyaratan yang lainnya juga dipenuhi, seperti nilai VIM, Flow dan sebagainya, hingga pada akhirnya memberi umur pelayanan jalan yang lebih lama. (Santosa, 1997).

Kadar aspal pada suatu campuran Asphalt Concrete Binder Course (AC BC) mempengaruhi nilai Specific Gravity (SG), Voids in Mix (VIM), Voids in Material Agregates (VMA), Voids Filled with Bitumen(VFB), Stability, Flow, dan Marshall Qoutient. Specific Gravity akan bertambah dengan bertambahnya kadar aspal sampai pada batas maksimum kemudian nilainya menurun. Voids in Mix menurun secara konsisten dengan bertambahnya kadar aspal. Voids in Material Agregates umumnya menurun sampai pada batas tertentu, kemudian naik dengan bertambahnya kadar aspal. Voids Filled with Bitumen secara konsisten bertambah dengan bertambahnya kadar aspal. Stability naik dengan bertambahnya kadar aspal sampai batas tertentu kemudian turun. Flow secara konsisten terus naik dengan bertambahnya kadar aspal. Marshall Qoutient bertambah dengan bertambahnya kadar aspal sampai batas tertentu kemudian menurun (Wirahaji, 2010).

Kadar aspal yang terpakai dalam campuran yang kemudian dihampar dilapangan adalah kadar aspal optimum. Kadar aspal optimum menjadi persyaratan mutlak dalam setiap campuran lapis perkerasan beraspal dimana besaran kadar aspal optimum berbedabeda, tergantung dari propertis aspal, agregat, gradasi agregat dan jenis campuran itu sendiri. Lapis perkerasan yang di atas selalu lebih besar kadar aspalnya. Hal ini disebabkan, karena aspal mampu mengisi rongga-rongga dalam campuran. Pengisian rongga-rongga ini dengan sendirinya akan memperkecil volume rongga, sehingga air tidak bisa masuk meresap ke lapisan aspal di bawahnya. Dengan kemiringan melintang badan 
jalan 2-4\% air hujan akan mengalir keluar badan jalan. Bila air dapat meresap ke dalam lapisan bawahnya, maka jalan akan segera rusak, tidak akan bertahan sesuai dengan umur rencana, yang biasanya direncanakan selama 10 tahun. (Dachlan, 2010).

Dimana dalam penelitian ini akan mempelajari Analisis Pembuatan Job Mix Formula Asphalt Concrete Binder Course (AC BC) pada Asphalt Mixing Plant (AMP) yang di produksi oleh AMP C punya PT. Hakaaston pada pelaksanaan pengaspalan Jalan Tol Palembang-Simpang Indralaya (Palindra) yang dilaksanakan di Laboratorium PT. Hutama Karya Infrastruktur yang merupakan kotraktor pelaksana pekerjaan Pembangunan Jalan Tol Palindra bersama dengan Konsultan supervisinya adalah PT. Cipta Strada serta pengawas HKJT yag mewakili PT. Hutama Karya, ketiga pihak secara bersama-sama melakukan sejumlah pemeriksaan/pengujian gradasi dan kadar aspal dengan seksama.

\section{RUMUSAN MASALAH}

Dari latar belakang di atas dapat dibuatkan rumusan masalah untuk memfokuskan analisis penelitian ini adalah:

1. Berapa kadar aspal optimum pada lapis Asphalt Concrete Binder Course (AC BC) yang diproduksi di AMP C milik PT. Hakaaston dalam pembuatan proses pembuatan Job Mix Formula (JMF) untuk Proyek Pengaspalan Tol Palindra?

2. Berapa nilai komponen-komponen Pengujian Marshall Test terhadap lapis Asphalt Concrete Binder Course (AC BC) yang diproduksi di AMP C milik PT. Hakaaston dalam pembuatan proses pembuatan Job Mix Formula (JMF) untuk Proyek Pengaspalan Tol Palindra?

\section{TUJUAN PENELITIAN}

Melihat rumusan masalah diatas dapat ditentukan bahwa penelitian ini bertujuan untuk mengetahui berapa kadar aspal optimum dan nilai komponenpada lapis Asphalt Concrete Binder Course (AC BC) yang diproduksi di komponen-komponen pengujian Marshall test yang diproduksi di AMP C milik PT. Hakaaston dalam pembuatan proses pembuatan Job Mix Formula (JMF) untuk Proyek Pengaspalan Tol Palindra.

\section{MANFAAT PENELITIAN}

\section{Manfaat Teoritis}

a. Menjadi bahan acuan bagi peneliti lain yang berminat meneliti tentang permasalahan yang terkait dengan kadar aspal optimum pada lapis Asphalt Concrete Binder Course (AC BC) yang diproduksi di AMP C milik PT. Hakaaston dalam pembuatan proses pembuatan Job Mix Formula (JMF) untuk Proyek Pengaspalan Tol Palindra.

b. Memberikan informasi pengembangkan ilmu teknik sipil yang berkaitan dengan kadar aspal optimum pada lapis Asphalt Concrete Binder Course (AC BC) yang diproduksi di AMP C milik PT. Hakaaston dalam pembuatan proses pembuatan Job Mix Formula (JMF) untuk Proyek Pengaspalan Tol Palindra. 


\section{Manfaat Praktis}

a. Memberikan informasi berapa kadar aspal optimum pada lapis Asphalt Concrete Binder Course (AC BC) yang diproduksi di AMP C milik PT. Hakaaston dalam pembuatan proses pembuatan Job Mix Formula (JMF) untuk Proyek Pengaspalan Tol Palindra.

b. Sebagai masukan bagi pihak-pihak terkait mengetahui karakteristik agregat, aspah curah yang dipakai dalam pembuatan lapis Asphalt Concrete Binder Course (AC BC) yang diproduksi di AMP C milik PT. Hakaaston dalam pembuatan proses pembuatan Job Mix Formula (JMF) untuk Proyek Pengaspalan Tol Palindra.

c. Sebagai pedoman dan rujukan bagi peneliti-peneliti lain, untuk melakukan penelitian yang terkait dalam pengembangan penelitian lebih lanjut.

\section{TINJAUAN TEORI}

\section{Aspal Sebagai Bahan Pengikat Campuran}

Aspal adalah material yang pada temperatur ruang berbentuk padat sampai agak padat, dan bersifat termoplastis. Aspal akan mencair jika dipanaskan sampai temperatur tertentu, dan kembali membeku jika temperatur turun. Banyaknya aspal sebagai bahan pengikat agregat dalam campuran perkerasan berkisar/antara $4-10 \%$ berdasarkan berat campuran atau 10-15\% berdasarkan volume campuran (Sukirman, 2003).

Secara garis besar komposisi kimiawi aspal terdiri dari asphaltenes, resins, dan oils. Asphaltenes terutama terdiri dari senyawa hidrokarbon, merupakan material yang berwarna coklat tua atau hitam. Asphaltenes menyebar di dalam larutan yang disebut maltenes. Maltenes berupa cairan kental yang terdiri dari resins dan oils. Resins cairan yang berwarna kuning atau coklat tua yang memberikan sifat adhesi pada aspal. Maltenes merupakan bagian yang mudah berubah sesuai dengan perubahan temperatur dan umur pelayanan. Durabilitas aspal merupakan fungsi dari ketahanan aspal terhadap perubahan mutu kimiawi selama proses pencampuran dengan agregat, masa pelayanan, dan proses pengerasan seiring waktu dan umur pelayanan (Sukirman, 2003).

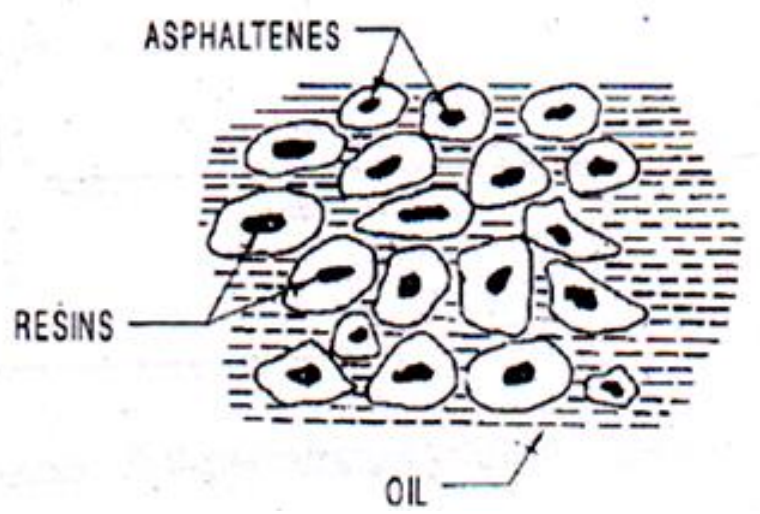

Sumber : Sukirman, 2003

Gambar 1. Komposisi aspal 
Pengerasan aspal dapat terjadi karena oksidasi, penguapan, dan perubahan kimiawi lainnya. Reaksi kimiawi dapat mengubah resins menjadi asphaltenes, dan oils menjadi resins, yang secara keseluruhan akan meningkatkan viscositas aspal.

Menurut Wignall (2003) aspal dapat dibagi menjadi 2 (dua), yaitu:

a. aspal alam

b. aspal buatan

Aspal alam dapat berasal dari batuan pegunungan (rock asphalt) dan danau (lake asphalt). Aspal buatan didapat dari proses destilasi minyak bumi, dengan pemanasan $350^{\circ} \mathrm{C}$ dibawah tekanan atmosfir untuk memisahkan fraksi-fraksi ringan, seperti gasoline (bensin), kerosene (minyak tanah), dan gas oil.

Hasil proses destilasi/penyulingan minyak tanah mentah menghasilkan 3 (tiga) macam aspal (Suryadharma, 2008), yaitu:
a. Aspal keras/panas (asphalt cement, AC)
b. Aspal dingin/cair (cut back asphalt)
c. Aspal emulsi (emulsion asphalt)

Penggunaan yang paling umum adalah jenis aspal keras (AC). Aspal jenis ini berbentuk padat pada temperatur antara $25^{\circ} \mathrm{C}-30^{\circ} \mathrm{C}$. Di Indonesia $\mathrm{AC}$ terdiri dari beberapa jenis, yaitu:
a. $\mathrm{AC}$ pen $40 / 50$
b. AC pen $60 / 70$
c. AC pen $80 / 100$
d. AC pen $120 / 150$
e. AC pen $200 / 300$

Di Indonesia umumnya dipakai AC pen 60/70 atau AC pen 80/100. Syarat umum AC adalah berasal dari saringan minyak bumi, harus mempunyai sifat yang sejenis, kandungan kadar parafinnya tidak lebih dari $2 \%$ dan tidak mengandung air/busa pada temperatur $175^{\circ}$ C.

Tabel 1. Klasifikasi Aspal Keras

\begin{tabular}{|c|l|c|c|c|c|}
\hline \multirow{2}{*}{ No } & \multirow{2}{*}{ Jenis Pemeriksaan } & \multicolumn{3}{|c|}{ Jenis Penetrasi } & \multirow{2}{*}{ Satuan } \\
\cline { 3 - 5 } & & Pen & Pen & Pen & Satu \\
& & $40 / 50$ & $60 / 70$ & $80 / 100$ & \\
\hline 1 & Penetrasi $25^{\circ} \mathrm{C}, 100$ gr, 5 detik & Min. 40 & Min. 60 & Min. 80 & $0.1 \mathrm{~mm}$ \\
\hline 2 & Titik Nyala & 200 & 200 & 225 & \\
\hline 3 & Daktilitas $25^{\circ} \mathrm{C}, 5 \mathrm{~cm}$ per menit & 75 & 75 & 100 & $\mathrm{~cm}$ \\
\hline 4 & Berat Jenis & 1 & 1 & 1 & $\mathrm{gr} / \mathrm{cm} 3$ \\
\hline
\end{tabular}

Sumber: Suryadharma, 2008

Penetrasi adalah besarnya kedalaman jarum penetrasi dapat menembus lapisan aspal pada suhu $25^{\circ} \mathrm{C}$ dengan beban sebesar 100 gram selama 5 detik (Revisi SNI 06-24561991). Pemeriksaan penetrasi dilakukan untuk mengetahui tingkat kekentalan atau kekerasan aspal. AC pen 60/70 berarti jarum penetrasi dapat menembus lapisan aspal sedalam 6-7 $\mathrm{mm}=(60-70) \times 0.1 \mathrm{~mm}$.

Titik Lembek adalah suhu pada saat bola baja, dengan berat tertentu mendesak turun suatu lapisan aspal yang tertahan dalam cincin berukuran tertentu, sehingga aspal tersebut pelat dasar yang terletak di bawah cincin pada tinggi $25.4 \mathrm{~mm}$, sebagai akibat kecepatan 
pemanasan tertentu (Revisi SNI 06-2434-1991). Titik lembek dipakai sebagai pedoman dalam melakukan pemadatan campuran aspal di lapangan. Campuran aspal tidak bisa dipadatkan pada saat suhu masih tinggi. Demikian juga tidak akan mau padat bila dipadatkan pada suhu di bawah titik lembek.

Titik Nyala adalah suhu pada saat terlihat nyala singkat kurang dari 5 detik pada suatu titik di atas permukaan aspal (SNI 032-2433-1991). Dengan diketahui suhu titik nyala ini dapat dipakai sebagai pedoman dalam pemanasan aspal.

Daktilitas aspal adalah nilai keelastisitasan aspal yang diukur dari jarak terpanjang, apabila antara dua cetakan berisi bitumen yang ditarik sebelum putus pada suhu $25^{\circ} \mathrm{C}$ dengan kecepatan tarik $50 \mathrm{~mm} /$ menit (SNI 06-2432-1991). Nilai daktilitas berpengaruh pada nilai flow campuran aspal.

Campuran aspal beton adalah kombinasi material bitumen dengan agregat yang biasa digunakan sebagai bahan perkerasan lentur jalan raya. Material aspal dipergunakan untuk semua jenis jalan raya dan merupakan salah satu bagian dari lapisan beton jalan raya kelas satu hingga dibawahnya. Material bitumen adalah hidrokarbon yang dapat larut dalam karbon disulfat. Material tersebut biasanya dalam keadaan baik pada suhu normal dan apabila kepanasan akan melunak atau berkurang kepadatanya. Ketika terjadi pencampuran antara agregat dengan bitumen yang kemudian dalam keadaan dingin, campuran tersebut akan mengeras dan akan mengikat agregat secara bersamaan dan membentuk suatu lapis permukaan perkerasan. (Putrowijiyo, 2006).

\section{METODOLOGI PENELITIAN}

Dalam penelitian ini, desain penelitian yang digunakan adalah penelitian kuantitatif, dimana penelitian dan pengujian ini dilakukan secara bertahap, yaitu terdiri atas pengujian agregat (kasar, halus dan filler), aspal dan pengujian terhadap campuran (Uji Marshall). Pengujian terhadap agregat termasuk analisa saringan, pemeriksaan berat jenis, pengujian abrasi dengan mesin Los Angeles, dan penyerapan air. Untuk pengujian aspal Shell AC 60/70 termasuk juga pengujian penetrasi, titik nyala-titik bakar, titik lembek, dan berat jenis.

Pengujian Marshall adalah suatu metode pengujian untuk mengukur ketahanan (stabilitas) terhadap kelelehan (flow) dari campuran aspal dengan menggunakan peralatan marshall. Pemeriksaan ini pertama kali dilakukan oleh Bruce Marshall, selanjutnya dikembangkan oleh U.S Corps of engineer. Pengujian marshall sekarang ini mengikuti prosedur dalam manual pemeriksaan bahan jalan (MPBJ) nomor PC-0202-76 atau American Association of state High way and Transportasion Official (AASHTO) nomor T-245 atau American Society for Testing and Materials (ASTM) nomor D 1559-62T.

Begitu juga didalam penelitian penentuan kadar aspal optimum pada lapis Asphalt Concrete Binder Course (AC BC) dalam pembuatan proses pembuatan Job Mix Formula (JMF) di Proyek Tol Palindra ini juga menggunakan Metode Marshall, dimana dari pengujian Marshall tersebut didapatkan hasil-hasil yang berupa komponen-komponen Marshall, yaitu: Stabilitas, Kepadatan (Density), Flow,(Void in the Mineral Aggregat/VMA), Rongga di dalam campuran (Void In The Compacted Mixture/ VIM), 
Rongga udara yang terisi aspal (Voids Filled with Bitumen/VFB), hasil bagi Marshall/Marshall Quotient (MQ) yang dilakukan di Laboratorium PT, Hutama Katya Insfrastruktur.

\section{HASIL DAN PEMBAHASAN PENELITIAN}

\section{Pemeriksaan Aspal Curah}

Aspal curah yang dipakai adalah Merk Shell 60/70 dari Singapura yang dipasok oleh Perusahaan PT. Rabana Aspalindo, sesuai dengan hasil pengujian yang dilakukan di Laboratorium Rekayasa Jalan dan Lalu Lintas Institut Teknologi Bandung pada sebagai berikut ini:

Tabel 2. Hasil Pemeriksaan Aspal

\begin{tabular}{|c|c|c|c|c|c|}
\hline No & Jenis Pemeriksaan & Prosedur & Spesifikasi & Hasil & Satuan \\
\hline 1 & Penetrasi pada suhu $25^{\circ} \mathrm{C}$ & $\begin{array}{l}\text { SNI 06-2456- } \\
\end{array}$ & & 63,2 & $0,1 \mathrm{~mm}$ \\
\hline 2 & Titik Nyala & $\begin{array}{l}\text { I 06-2434- } \\
1991\end{array}$ & in & 344 & ${ }^{\circ} \mathrm{C}$ \\
\hline 3 & Titik Bakar & $\begin{array}{c}\text { SNI 06-2434- } \\
1991\end{array}$ & & 350 & ${ }^{\circ} \mathrm{C}$ \\
\hline 4 & Titik Lembek $Z$ & $\begin{array}{c}\text { SNI 06-2433- } \\
1991\end{array}$ & $48-56$ & 51 & ${ }^{\circ} \mathrm{C}$ \\
\hline 5 & $\begin{array}{l}\text { Pemeriksaan Berat Jenis } \\
\text { Aspal }\end{array}$ & $\begin{array}{c}\text { SNI 06-2441- } \\
1991\end{array}$ & & 1,037 & $\mathrm{Kg} / \mathrm{m}^{3}$ \\
\hline 6 & Pemeriksaan Daktilitas & $\begin{array}{l}\text { SNI 06-2441- } \\
\text { T } 1991\end{array}$ & & $>100$ & $\mathrm{Cm}$ \\
\hline 7 & Kelarutan dalam TCE & $\begin{array}{c}\text { SNI 06-2438- } \\
1991\end{array}$ & Min. 99 & 99.70 & $\%$ Berat \\
\hline \multirow[t]{3}{*}{8} & $\begin{array}{l}\text { Penetrasi Setelah } \\
\text { Kehilangan Berat }\end{array}$ & & $50-80$ & 61.3 & $0,1 \mathrm{~mm}$ \\
\hline & $\begin{array}{l}\text { Persentase Perbedaan } \\
\text { Penetrasi Setelah TFOT } \\
\% \text { Asli }\end{array}$ & $\begin{array}{l}\text { SNI 06-2456- } \\
1991\end{array}$ & Max. 40 & 3.0 & $\%$ \\
\hline & $\begin{array}{l}\text { Persentase Terhadap } \\
\text { Penetrasi Asli }\end{array}$ & & Min. 54 & 97 & $\%$ \\
\hline 9 & Kadar Parapin & $\begin{array}{c}\text { SNI 06-3639- } \\
1991\end{array}$ & Max. 2 & 0.147 & $\%$ \\
\hline
\end{tabular}

Sumber: hasil penelitian

\section{Pemeriksaan Agregat}

Agregat terdiri dari Abu batu, agregat ukuran 10-10 mm (Mediun Aggregat) dan 10-20 mm (Coarse Aggregat) yang semua berasal dari Ciwandan Merak Banten yang disediakan oleh PT. Diaz, sesuai dengan hasil pengujian yang dilakukan di di Laboratorium 
PT. Hutama Karya Infrastruktur di Jalan Musi 2 Kota Palembang yang hasilnya sebagai berikut ini:

Tabel 3. Proporsi Campuran

\begin{tabular}{|l|c|l|c|}
\hline \multicolumn{2}{|c|}{ Cold Bin } & \multicolumn{2}{c|}{ Hot Bin } \\
\hline \multicolumn{1}{|c|}{ Material } & Prosentase (\%) & \multicolumn{1}{c|}{ Material } & Prosentase (\%) \\
\hline 1. Coarse Agg.1 - 2 & & 1. Hot Bin IV & $\mathbf{4 5 , 0 \%}$ \\
\hline 2. Medium Agg. & $\mathbf{2 8 , 0 \%}$ & 2. Hot Bin III & $\mathbf{2 7 , 0 \%}$ \\
\hline 3. Abu Batu & $\mathbf{3 2 , 0 \%}$ & 3. Hot Bin II & $\mathbf{1 8 , 0 \%}$ \\
\hline 4. Asphal Shell & $\mathbf{5 , 3 \%}$ & 4. Hot Bin I & $\mathbf{1 0 \%}$ \\
\hline
\end{tabular}

Sumber: hasil penelitian

Tabel 4. Gradasi Gabungan

\begin{tabular}{|l|c|c|c|}
\hline \multirow{2}{*}{ Sieve } & \multicolumn{2}{|c|}{ Gradasi Gabungan } & \multirow{2}{*}{ Spec } \\
\cline { 2 - 4 } & Hot Bin & Extraction & \multirow{2}{*}{ Kadar Aspal Optimum } \\
\cline { 2 - 4 } & Combine & $\mathbf{( 5 , 3 \% )}$ & \\
\hline $2 "$ & 100 & 100 & 100 \\
\hline $11 / 2 "$ & 100,00 & 100,00 & 100 \\
\hline $1 "$ & 100,00 & 100,00 & 100 \\
\hline $3 / 4 "$ & 91,59 & 91,59 & $90-100$ \\
\hline $1 / 2 "$ & 80,30 & 81,17 & $75-90$ \\
\hline $3 / 8 "$ & 72,18 & 73,24 & $66-82$ \\
\hline No. 4 & 52,58 & 54,42 & $30-49$ \\
\hline No. 8 & 32,65 & 33,93 & $18-38$ \\
\hline No. 16 & 21,72 & 22,84 & $.12-28$ \\
\hline No. 30 & 15,01 & 16,36 & $7-20$ \\
\hline No. 50 & 11,60 & 12,80 & $5-15$ \\
\hline No. 100 & 8,26 & 8,85 & $.4-8$ \\
\hline No. 200 & 5,00 & 5,20 & \\
\hline
\end{tabular}

Sumber: hasil penelitian

Tabel 5. SP. Gr \& Absortion Gabungan Hot Bin

\begin{tabular}{|l|c|c|c|}
\hline \multicolumn{1}{|c|}{ Material } & $\begin{array}{c}\text { SP.Gr. } \\
\text { Bulk }\end{array}$ & $\begin{array}{c}\text { SP.Gr. } \\
\text { APP }\end{array}$ & Penyerapan Air \\
\hline HOT BIN IV & 2,499 & 2,640 & 2,1457 \\
\hline HOT BIN III & 2,559 & 2,663 & 1,532 \\
\hline HOT BIN II & 2,628 & 2,683 & 0,780 \\
\hline HOT BIN I & 2,637 & 2,680 & 0,608 \\
\hline
\end{tabular}

Sumber: hasil penelitian 


\section{Pengujian Marshall Test dan Prd}

Terlebih dahulu dilakukan Trial Asphalt Mixing Plant (AMP C ) untuk menentukan kadar aspal optimum pada lapis Asphalt Concrete Binder Course (AC BC) yang diproduksi di AMP C milik PT. Hakaaston dalam pembuatan proses pembuatan Job Mix Formula (JMF) untuk Proyek Pengaspalan Tol Palindra maka di pakai aspal curah yang dipakai adalah Merk Shell 60/70 dari Singapura yang dipasok oleh Perusahaan PT. Rabana Aspalindo yang dibuatkan berbagai variasi sample marshall tes dengan kandungan aspal mulai dari 4,5\%, 5,0\%, 5,5\%, 6,0\% dan 6,5\% sedangkan agregat terdiri dari Abu batu, agregat ukuran 10-10 mm (Mediun Aggregat) dan 10-20 mm (Coarse Aggregat) yang semua berasal dari Ciwandan Merak Banten yang disediakan oleh PT. Diaz, sesuai dengan hasil pengujian yang dilakukan di di Laboratorium PT. Hutama Karya Infrastruktur di Jalan Musi 2 Kota Palembang, dimana hasil pengujian Marshall testnya didapat kadar aspal optimum di 5,3\% untuk proses pembuatan Job Mix Formula (JMF) untuk Proyek Pengaspalan Tol Palindra, detailnya sebagai berikut ini:

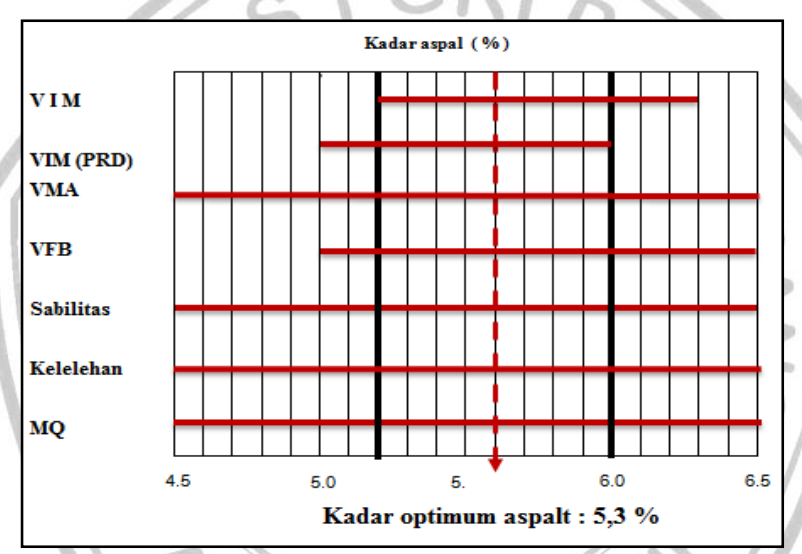

Sumber: hasil penelitian

Gambar 2. Grafik Penentuan Kadar Aspal Optimum

Tabel 6. Marshall Tes dan Prd

\begin{tabular}{|c|c|c|c|c|c|c|c|c|}
\hline $\begin{array}{l}\text { Kadar } \\
\text { Aspal }\end{array}$ & Density & VMA & VFB & VIM & Stability & Flow & M.Q & VIM PRD \\
\hline$\%$ & Gram/cc & $\%$ & $\%$ & $\%$ & $\mathrm{Kg}$ & $\mathrm{mm}$ & $\mathrm{Kg} / \mathrm{cm}$ & $\%$ \\
\hline 4,5 & 2,258 & 15,45 & 60,53 & 6,098 & 1249,5 & 3,60 & 291,7 & - \\
\hline 5,0 & 2,272 & 15,38 & 65,63 & 5,285 & 1153,5 & 3,40 & 339,3 & - \\
\hline 5,5 & 2,302 & 14,73 & 74,11 & 3,814 & 1276,4 & 3,30 & 386,7 & - \\
\hline 6,0 & 2,321 & 14,49 & 80,22 & 2,865 & 1115,7 & 3,60 & 310,3 & - \\
\hline 6,5 & 2,330 & 14,58 & 86,27 & 2,002 & 1040,1 & 3,80 & 273,7 & - \\
\hline \multicolumn{9}{|l|}{ PRD } \\
\hline 4,5 & 2,295 & - & - & - & - & - & - & 4,59 \\
\hline 5,0 & 2,317 & - & - & - & - & - & - & 3,41 \\
\hline 5,5 & 2,345 & - & - & - & - & - & - & 2,01 \\
\hline
\end{tabular}

Sumber: hasil penelitian 
Tabel 7. Hasil JMF / Trial Mix dan Trial Compaction

\begin{tabular}{|l|c|c|}
\hline \multicolumn{1}{|c|}{ Mix Propertis } & Test Result & Spec. \\
\hline 1. Asphalt Content & 5,30 & - \\
\hline 2. Stability & 1314,25 & Min. $1000 \mathrm{Kg}$ \\
\hline 3. Void in Mix & 4,57 & $3.0-5.0 \%$ \\
\hline 4. Void in Mix ( PRD ) & 2,63 & Min. 2 \\
\hline 5. Void Mineral Aggregate & 15,18 & Min. 14 \\
\hline 6. Void Filled With Asphalt & 69,86 & Min. 65 \\
\hline 7. Flow & 3,45 & $2,0-4.0 \mathrm{~mm}$ \\
\hline 8. Marshall Quotient & 254,04 & - \\
\hline 9. Density & 2,285 & - \\
\hline 10. Retained Stability & 31,37 & Min. 90 \\
\hline 11. Absorption Asphalt & 0,51 & - \\
\hline 12. Kepadatan Lapangan & - & $1-1.4$ \\
\hline 13. (\%) Ratio lolos 200 Terhadap & $G \mathrm{P}, 08$ & \\
Kadar Aspal Effektif & & \\
\hline
\end{tabular}

Sumber: hasil penelitian

\section{KESIMPULAN}

Penentuan kadar aspal optimum harus melalui langkah-langkah yang telah ditentukan dalam dokumen kontrak. Dalam hal ini buku spesifikasi Tol Palindra, dengan memperhatikan sifat-sifat alami material pembentuk campuran aspal dan sejumlah persyaratan campuran aspal. Dari pembahasan di atas ada beberapa hal yang dapat disimpulkan, yaitu:

1. Kadar aspal optimum pada lapis Asphalt Concrete Binder Course (AC BC) yang diproduksi di AMP C milik PT. Hakaaston dalam pembuatan proses pembuatan Job Mix Formula (JMF) untuk Proyek Pengaspalan Tol Palindra didapat 5,3\% denagn agregat terdiri dari Abu batu, agregat ukuran 10-10 mm (Mediun Aggregat) dan 10-20 mm (Coarse Aggregat) yang semua berasal dari Ciwandan Merak Banten yang disediakan oleh PT. Diaz, sesuai dengan hasil pengujian yang dilakukan di Laboratorium PT. Hutama Karya Infrastruktur di Jalan Musi 2 Kota Palembang.

2. Hasil pengujian karakteristik Marshall Test pada Kadar Aspal Optimum 5,5\% pada lapis Asphalt Concrete Binder Course (AC BC) yang diproduksi di AMP C milik PT. Hakaaston dalam pembuatan proses pembuatan Job Mix Formula (JMF) untuk Proyek Pengaspalan Tol Palindra adalah sebagai berikut:

a. Nilai Density diperoleh sebesar 2,285 gr/cc.

b. Nilai VMA (Void in Mineral Aggregat) sebesar 15,18\%.

c. Nilai VFB (Void Filled Bitumen) sebesar 69,86\%.

d. Nilai VIM (Void In Mix) sebesar 4,57\%.

e. Nilai Stabilitas Marshall sebesar $1314,25 \mathrm{~kg}$.

f. Nilai Flow (kelelehan) sebesar 3,45 mm.

g. Marshall Quotient diperoleh sebesar $254,04 \mathrm{~kg} / \mathrm{mm}$ 


\section{DAFTAR PUSTAKA}

AASHTO T 96. 2001. Standard Method of Test for Resistance to Degradation of SmallSize Coarse Aggregate by Abration and Impact in the Los Angeles Machine.

Badan Standarisasi Nasional. 2002. Standar Nasional Indonesia. Jakarta: PusjatanBalitbang PU.

Dachlan, A Tatang. 2010. Uji Kepadatan Membal (Refusal Density) Untuk Meningkatkan Kesesuaian Mutu Perkerasan Jalan Beraspal. http://www.scribd.com/henra_syam /d/31519160-9- Uji-Kepadatan-Membal. Diakses tanggal 30 Januari 2012.

Puslitbang Teknologi Prasaranan Jalan. 2000. Pedoman Perencanaan Campuran Beraspal Panas Dengan Pendekatan Kepadatan Mutlak. Bandung: Departemen Pemukiman dan Pengembangan Wilayah.

Putrowijoyo, R. 2006. Kajian Laboratorium Sifat Marshall dan Durabilitas Asphalt Concrete-Wearing Course (AC-WC) Dengan Membandingkan Penggunaan Antara Semen Portland dan Abu Batu Sebagai Filler. Semarang: Program Pasca Sarjana Jurusan Teknik Sipil, Fakultas Teknik, Universitas Diponegoro.

Revisi SNI 03-1737-1989. Pedoman Tentang "Pelaksanaan lapis campuran beraspal panas" adalah pengganti dari SNI 03-1737-1989, Tata cara pelaksanaan lapis aspal beton (LASTON) untuk jalan raya: Badan Litbang Departemen Pekerjaan Umum.

Revisi SNI 03-1737-1989. Pedoman Tentang "Pelaksanaan lapis campuran beraspal panas" adalah pengganti dari SNI 03-1737-1989, Tata cara pelaksanaan laapis aspal beton (LASTON) untuk jalan raya: Badan Litbang Departemen Pekerjaan Umum.

Revisi SNI 06-2456-1991. Uji Penetrasi Aspal: Badan Litbang Departemen Pekerjaan Umum.

Revisi SNI 06-2434-1991. Cara uji titik lembek aspal dengan alat cincin dan bola (ring ang ball): Badan Litbang Departemen Pekerjaan Umum.

RSNI M-01-2003. Metode Pengujian Campuran Beraspal Panas dengan Alat Marshall: Badan Standarisasi Nasional.

RSNI M-06-2004. Metode Pengujian Campuran Beraspal Panas dengan Alat Marshall: Badan Standardisasi Nasional.

Santosa, Wimpy. 1997. Mengenal Sifat Kepekaan Temperatur Aspal. Bandung: FT Univ. Katolik Parahyangan.

SNI 03-1968-1990. Metode Pengujian Analisa Saringan Agregat Halus dan Agregat Kasar: Pustran Balitbang Pekerjaan Umum.

SNI 03-2417-1991. Metode Pengujian Keausan Agregat Dengan Mesin Abrasi Los Angeles: Pustran Balitbang Pekerjaan Umum.

SNI 06-2441-1991. Metode Pengujian Berat Jenis Aspal: Pusjatan- Balitbang PU. 
Sukirman, Silvia. 2003. Beton Aspal Campuran Panas. Jakarta: Granit.

Suryadharma, Hendra. 2008. Rekayasa Jalan Raya. Yogyakarta: Univ. Atma Jaya.

Thanaya, Arya. 2008. Perkerasan Jalan. Buku Ajar Mata Kuliah Teknologi Bahan. Denpasar: FT Unud.

Wirahaji. 2010. Beton Aspal-Campuran Panas. Jakarta: Granit.

Wignall, Arthur, dkk. 2003. Proyek Jalan Teori dan Praktek. Edisi ke empat. Jakarta: Erlangga.

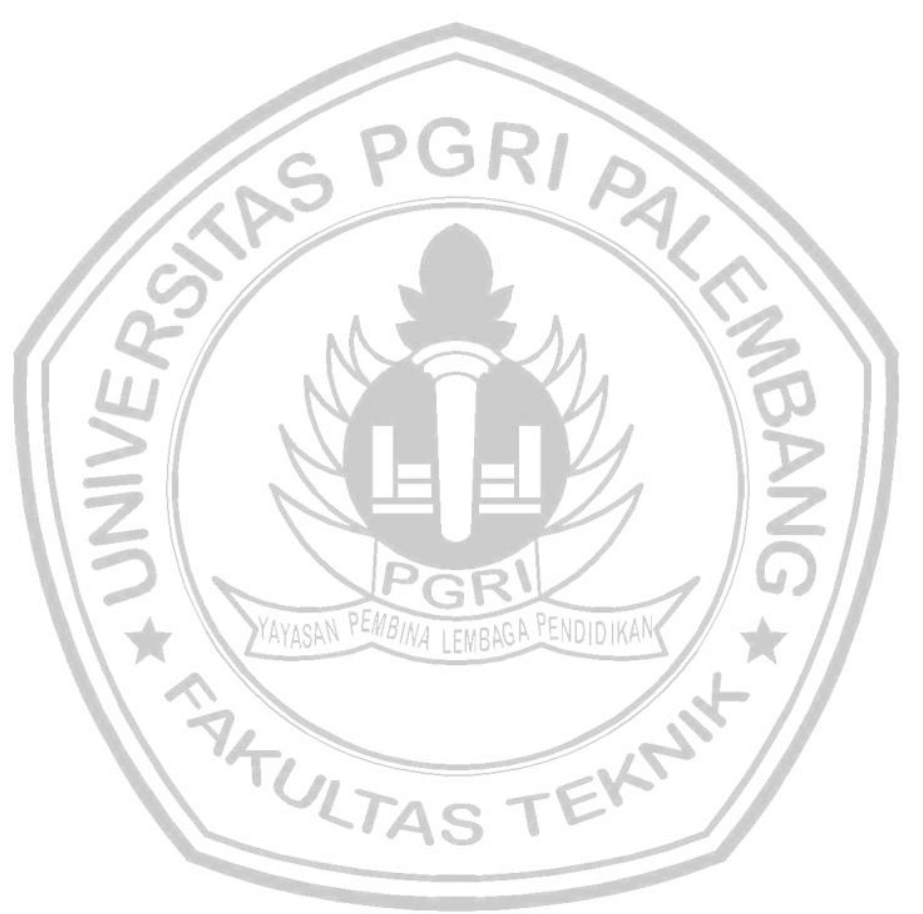

